\title{
Inner Alienation: Diasporic Consciousness in Kamila Shamsie's Salt and Saffron
}

\author{
Humaira Riaz (Corresponding author) \\ Fatima Jinnah Women University, Rawalpindi, Pakistan \\ E-mail: fawad_humaira@yahoo.com \\ Ruzbeh Babaee \\ Faculty of Modern Languages and Communication, University Putra Malaysia, Malaysia \\ E-mail: ruzbeh_babaei@upm.edu.my
}

Doi:10.7575/aiac.alls.v.6n.5p.163

URL: http://dx.doi.org/10.7575/aiac.alls.v.6n.5p.163
Received: $24 / 05 / 2015$

Accepted: 02/08/2015

\begin{abstract}
The purpose of this study is to investigate the 'diasporic consciousness 'of the fictional characters, incorporated in selected work of Pakistani expatriate writer Kamila Shamsie through the portrayal of cross-cultural differences. This study attempts to unravel the inner-alienation that sustains through specific discourses and events occurring in the lives of the expatriate fictional characters represented in Salt and Saffron (2000). The composite term used for this study is 'diasporic consciousness' that refers to a specific kind of awareness dominant among the contemporary transnational communities. It is also said to possess a dual nature. More specifically, it is defined in relationship to the memories of the homeland. It emphasizes on describing a myriad of experiences showing a particular state of mind and most prominently a sense of identity. Shamsie's Salt and Saffron portrays the cross-cultural differences between Karachi and New York, and explores an irrational fear of place in which the characters initially find themselves trapped in.
\end{abstract}

Keywords: Diaspora, Consciousness, Inner-Alienation, Culture

\section{Introduction}

Human beings are endowed by nature to imagine, think and reason. It is these attributes that make them distinct from the other creatures in the world. Their thinking capability and interaction within their social and cultural spheres shape their characters. They recognize and engage themselves into various social concerns. With these apprehensions in minds, movement for socio-economic and educational betterment has become a popular phenomenon with human beings for the past years. The need for socio-economic stability has compelled people to move into different domains of life even away from their birth places and relationships to settle and work in foreign countries acquiring the position of 'expatriates'. There has always been a huge line of demarcation between Eastern and Western cultures and societies. Culture is so deeply woven in the societies and consciousness is raised when people face cultural differences. This specifically occurs to those who are displaced from their own regions and cultures.

\section{Diaspora}

The framework that has been adopted for the current research is based on the larger context of Diaspora Studies. The origin of the term 'diaspora' is traced in the Greek translation of the Old Testament around 250BC. According to Rushdie (1983), diasporas are people 'floated upwards from history, from memory, from Time' (p. 91). Furthermore, Appadurai \& Breckenridge (1989) stated that Diasporas always trailed of collective memory about another place and time and created new maps of desire and of attachment. The present study, however, is further limited to use William Safran's model of Diaspora (1991).Safran (1991) chooses the broader definition of Walter Connor describing Diaspora 'as that segment of the people living outside their homeland' (p.83) and narrows it down to 'expatriate communities'. He further defines 'diasporic consciousness' as a state of mind and a sense of identity. It is a particular kind of awareness generated among contemporary transnational communities (Safran, 1991). This study attempts to investigate how well the social and cultural factors in selected novel indicate the 'diasporic consciousness' leading to inner alienation.

\section{The Cross-Roads of Cultures}

In Salt and Saffron the female protagonist, Aliya portrays a desire to be in and out of homeland at the same time. Aliya is a victim to the family history that connects it to the days of Taimur Lung. She goes through the experiences of developing a consciousness surrounded with its cross-cultural confusions. She lives in the 'mortal fear of not-quitetwins' (Salt and Saffron: 1). Shamsie effectively uses long descriptions to illustrate the protagonist' consciousness to the place as well as environment. This also displays her 'aesthetic enthusiasm' (Blunt \&Rose1994:61) towards her homeland: 
...trees and houses and electricity poles silhouetted against the sky...the rustle of the leaves was a benediction. Karachi's nights remind you that you can love a place, and for me that's always been a reason to rejoice (Salt and Saffron: 172).

This conceptual relationship with homeland exposes the inner conflict that arises while her stay in America. Calling the modern airports a hindrance 'deny [ing]' the immigrants from feeling at home, Aliya reveals how strongly she is possessed by the feelings of dispersion. She has 'always loved the brashness of that city" (Salt and Saffron: 85). Aliya is caught between 'the 'dual or paradoxical nature' (Cohen1997) of the consciousness from the very beginning. Although she calls the idea of 'Not - Quiets' is more like 'bugaboo' that means 'object of baseless terror', being an expatriate, she admits the fact of being an 'other' (Said: 1978) throughout the novel. It depicts her feelings of living in isolation that leads her to the fear of not being accepted by the foreign society. A continuous skirmish is seen throughout the action, resentment towards the foreign culture and yearning for the life spent in the homeland. Binary forces are seen at work which keeps her disconcerted. Forces of time and space hold her under a strict and horrifying influence. As a matter of fact she enjoys a sound economic position and seems to be concerned with her social real 'self'. These undercurrents bridge the past with the present beholding a new horizon.

Aliya exemplifies a young woman, quite independent, as she goes to America for studies with a desire to return home. "It takes more than a Nepalese ox to distract attention away from my family..." (Salt and Saffron: 3).It reflects her consciousness about her state of ambivalence which does not permit her anxiety to settle down. What probably make her character 'insulated' and 'alienated' (Safran1991) from the host society are her feet into two boats simultaneously. There is always something going around in her mind about where she is. She considers place and not identity the main point of conflict. She compares the immigrants to the "commas and exclamation marks". They need to describe their status to the world. They are filled with confusions and surprises; still they are the significant part of their host community as they are adding culture, color and labour to it. Yet they are underestimated for life long. "Why is it when people exchange recipes they so often forget to mention salt?"(Salt and Saffron: 178)

The dilemma of estrangement is understood more in Shamsie's meditation on loss of an emotional location. She explores the pain that an immigrant feels by depicting the partition story. The 'space' that Aliya occupies in host land is unthinkable in her homeland as there are many barriers of communication and relationships in the systems. In contrast Khalil, another immigrant who exposes his background to Aliya by 'slurping' the tea is conscious of his middle class origin in Karachi. He finds America a better place to live in since it offers no class distinction. Yet he knows he is not fully accepted in the host country.

Cultures leave imprints on the people's life wherever they are. It is evolved from the spatial forms and fantasies. Every culture has a rich and vast history. In the case of immigrant characters a multi web of the cultures is knitted around. It amalgamates those who face it. Aliya reacts to her surrounding abruptly. This happens to her mainly due to the fact that she has no shoulder to comfort her in that foreign land. Multiple faces appear in the back drop of memory, fantasy, narrative and myth. Aliya aspires to her coming back home from her United States. The space between Karachi (Pakistan) and United States provides her a deep and better vision into the cultural differences that her whole life has been entrenched in. Even aunt Starch and her family are desperately following the foreign culture. This exemplify that the first generation immigrants have a constant fear of being away from their roots; the danger of which they foresee in their next generation. The cross cultural differences create space alienation between the immigrants and the indigenous people due to the fact that South Asian family patterns are closely knit into relationships and ties. Other characters such as Dadi, MehrDadi and Taimur are profoundly connected by the facts of migration, cross cultural differences and the new identities that emerge as a result.

Food, clothes and family relations dominate all Asian cultures. Shamsie uses these as tools to preserve the traditions while living abroad. She gives exclusive descriptions about food, clothes and relationships to make it evident that the expatriates cannot escape from craving. She draws food analogies (Tamarind sounds like Taimur Hind to Aliya) to depict the expatriate character growing sensitive about their belongings. However, some expatriates believe in cultural identity an adopted object rather than an inherited one. Aliya foregrounds this reality:

My cousin, Samia had become a sandwich eater, Bread, mayonnaise, mustard, salami, sliced roast beef lettuce, tomatoes.... tuna salad. Good God, how dreary... Behind the loaf of bread was a sauce boat, not dissimilar in size and shape to Aladdin's lamp (Salt and Saffron, 21).

For Aliya the journey back home is a factor that instills in her happiness. Travelling has instigated to enquire the questions about her family and herself. She desperately tries to trace the family history in order to have recognition. Her family being immigrants from India faces the trauma of dispersal. They build new homes and relationships in Pakistan. However, the dispersal never let them feel happy at the memories of those they left behind. Aliya believed memories cripple our life rather than making them comfortable and happy (p. 32). This conforms to what Rutherford (1990) stated about migration that it disorientates and ruptures identities. Spatial and temporal 'coordinates' are removed which are believed to be important for a consciousness about past and origin. Consciousness can be analyzed conveniently only if time and space is considered. Aliya draws a strong connection between the past and the present for a better future to linger upon. This indicates the development of her consciousness. 
In Salt and Saffron, the norms and values of the society are better understood in the different family interactions and multifarious narratives told by different characters. More specifically the story of Maryam Apa and Masood's elopement makes the perspective of the novel quite open for the readers. Interestingly, the diasporic characters in Shamsi are settled in Greek, Iran and Turkey where their experiences of life are the same as in US and England. Masood and Maryam are perceived to settle and open a restaurant in Turkey and make their lively- hood in a foreign land; food being their connection and identity. Thus, as discussed earlier, the importance of food as a cultural tie is emphasized. Maryam is depicted as a symbolic character of the new generation who believes in humanity rather than the class distinction which her family is so absorbed in.

Hypocrisy lend expression to the inside state of mind and heart. At times Shamsie's characters can be seen as hypocrites. They are found bragging about their family history but down at heart they yearn for them. The expatriate writers depict 'rooting of memory in place' (Nayar, 2008, p.61). But these are descriptions of partial memories. 'Collective memory' is recovered on a limited scale as the second generation immigrant characters have an entirely different notion of 'home'.(Safran1991)

Partition is viewed as yet another form of exile in Salt and Saffron. Shamsie's tale of partition is a powerful tool to educate the readers about certain facts of history and exile. Dadi, MehrDadi, Taimur and the rest migrated to Pakistan at the time of partition but they always yearn for their ancestries. They apparently despise those whom they had left behind but at last make a confession of being a part of them. MehrDadi expresses her feelings in the novel:

I miss my family. You all drive me mad but coming back to Karachi is like stepping into the sea again after months on land. How easily you float, how peaceful is the sense of being born along, and how familiar the sound of the water lapping against your limbs (Salt and Saffron. 220).

Dadi's conversation with Aliya about her past life in India depicts her great emotions on the loss of her country and realization that she cannot go back to India:

It's all very well to love a place, but in the end what matters most is the people who live there. ... She pushed my hair off my face. 'Let it go, my darling. Some people leave our lives, it happens. People leave. Let it go.(Salt and Saffron, 183-204)

The consciousness in Shamsie's characters is rooted in the past memories. It informs about 'desire', a spirit of longing and want of satisfaction (Isasi-Diaz: 2004). She is conscious of the events which took place in the past. The main structure of the novel is dependent upon the family history before partition. Language is also a powerful feature in sustaining the consciousness. In Salt and Saffron there is a beauty to describe the cult of the family and most prominently the language differentiations:

Pride! In English it is a deadly sin but in Urdu it is Fakhr and Nazish__ both names that you can find more than once on our family tree. You must go back to those names, those people, in order to understand who I am and who you are (p.20).

The idea of 'home' keeps on developing in the discourses and events throughout the novel by 'transplantation of names, the mixing of languages and the diversification of tastes'. (Boehmer 1995).Immigrant characters show 'sensitivity' (Boehmer 1995) towards their roots. James Clifford calls it an 'awareness of discrepant attachments' (p. 248). Aliya shows this attachment by experimenting technique of inserting vocabulary from her mother tongue so that she could conceptualize her 'being' in it (Boehmer 1995). She shows gratitude to the language she owns. She calls it preserving of the true sense the words reveal rather than the substitutes. Shamsie desperately draws family tree throughout the novel. Initially it was confusing, but she completed it with her mastery making it vivid to the readers. Although we find a conventional dramatic revelation at the end, there is much to notice how the consciousness of Aliya leads her to find the final truth. She is lost in the stories of the partition. Still she efforts to understand her family tree. Aliya's family members are lost in recalling the events that directly or indirectly join them to their 'roots'.

Diasporic consciousness features a sense of alienation in a new society and culture. When we talk of alienation, we try to explore its nature. Aliya is alienated and put in a quest for self-identification. However, we do not find her speaking for a 'psychological or physical' liberation. It seems she is contended when she finds answers at the end of her quest. For Shamsie duality has always been regarded as an absurd thing. This duality has been incorporated in Aliya's character. It is evidently felt when Aliya remarks: “'Decisions,' I said, hoisting myself on the kitchen counter, 'where, what, why. Can't handle them. So I'm prolonging the indecision with higher education" (Salt and Saffron, 19). We find that the displacement and ambivalence arise from a source more internal. Shamsie's detailed portrayal of Indo-Pak history conforms the fact about history as 'mankind's painfully purchased experience, now available free or merely for the price of attention and reflection (Sowell 1994, p. 224). What we feel pride in, may well cause fury and depression in those who literally had undergone those pains of leaving their homes, properties and most of all land. Salt and Saffron narrates the class and caste system clearly. Aliya being a part of social hierarchy realizes that she herself has been caught inthe same web. Most particularly when she learns about Khalil's residence in Karachi, she feels embarrassed in front of her cousin. She is deeply scared of his family background because of her relatives' 'inbred snobbery' (Salt and Saffron, 33). Shamsie highlights the fact that colonialism has affected the minds of the people in a way that even after freedom they cannot come out of its influences. Yet a silent resentment is there. Finally it is revealed to Aliya that few 
Dar- de- Dils are connected in imagination to their Indian relatives even after long years of imagination. Dar- de - Dils symbolizes a particular community of the expatriates who are of the consciousness of its origin in Indian soil. Dadi, Ama, Aba, MehrDadi are representatives of this community. Even their second generation such as Sameer, Samia and particularly Aliya pursue their family history. This shows the awareness of the expatriates who question their identity and origin. Shamsie consciously interprets her cultural values, language and traditions in Salt and Saffron. Dadi's collection of family photographs and frames decorated in drawing rooms show esteem for the ancestral homeland, relatives and family ties. Shamsie uses fine parables to describe the final return of Sulaiman who discloses the whole suspense although in a conventional manner the story is resolved.

The myth about non-quite twins throughout the story can also be analyzed as a story of a person with two aspects of personality. Two sides are altogether different. On one side, there are feelings and emotions attached to the origin of one's existence. On the other hand, there is 'cloning; that is positioning one's self extremely according to the structure of the foreign land. Not -quiets are different altogether in appearance. The concept of non-quiets is used in the novel to show belonging to different worlds. It also indicates moving from one border to another thus bringing change in the identities of immigrant characters by 'being Westerners in the East to being Easterners in the West' (Rausing, 2002, p. 138). One is indulged always in the process to settle 'the nature versus nurture debate' as Shamsie calls it (Salt and Saffron, 121). The original side of the personality has always been in battle with the outsider, thereby, making the feelings of alienation stronger. Throughout a battle is seen highlighting the very existence of the not-quiets in Dar de Dil family; the not - quiets are the harbingers of change.

Shamsie brings forth the point that one's self-determination and purity of culture has been lost “...clarity and purity that was lost in multitude. It was that way with family histories too..." (Salt and Saffron, 116). She believes in the deep study of history 'to isolate each life' and investigate how the '....discordant note .... Echoed in this life and ... transformed into a necessary part of the whole...' (p.117). Self -revelation is possible when an individual suffers the thick and thin of life. Calling England a 'neutral soil' (p: 91) Shamsie is sarcastic of the fact that this soil offers us neither love nor hatred. We share an estrangement that makes us different form the local people of England, America or any place around the world. Aliya weighs her situation and finally resolves the conflict by yielding to accept the change .This acceptance is without bewilderment. For her a serene moment of life is union with Khalil.

\section{Conclusion}

Exposure to a new environment is a great cause of the growing consciousness. Loyalties may not change but there is an unwanted unconscious or conscious acceptance of the new and what is present. That may be called a bitter reality of life. History shows that human beings adapt themselves to the environments. Moreover, social and economic constraints cause distress in their lives. Their consciousness is raised because they feels and face difference all around them. The expatriate characters suffer from trait anxiety which means the anxiety is a component of their personality. They feel their identity is threatened even if they are in a secure environment. The consciousness is about their respective cultures comprising of traditions, relationships, food, clothes and language.

\section{References}

Appadurai, A., \& Breckenridge, X. (1989). 'On Moving Targets. Public Cultur2 (1), i-iv. http: // public culture. duke journals.org/content/22/2/v/.full pdf.

Blunt, A., \& Rose, G. (Eds.). (---). Writing Women and Space Colonial and Postcolonial Geographies. New York \& London: The Guilford Press.

Boehmer. E. (1995).Colonial and Postcolonial Literature. Oxford \& New York: Oxford University Press.

Clifford, J. (1994). 'Diasporas'.CulturalAnthropology.9(3). http://wayneadwax.com/pdf/Clifford_diaspora.pdf.

Cohen, R. (1997). Global Diaspora: An Introduction. London: UCL Press.

Isasi-Díaz, M. (2004). Retrieved from library.columbia.edu/content/dam/libraryweb/.../fa/.../ldpd_5628306.pdf

Nayar, P. (2008). Postcolonial Literatures; An Introduction. New Delhi: Pearson Longman.

Rausing S. (2002). Reconstructing the "normal": Identity and consumption of Western goods in Estonia. In: Mandel Ruth, Humphrey Caroline., editors. Markets and moralities: Ethnographies of Post socialism. Oxford: Berg.

Rushdie, S. (1983). Shame. New York: Alfred A. Knopf.

Rutherford ,J. (1990). ‘A Place Called Home’ In Identity: Community, Difference. London: Lawrence.

Safran, W. (1991). 'Diaspora in Modern Societies: Myth of Homeland and Return' In Diaspora 1 https://www.academia.edu/5029348/Diasporas_in_Modern_Societies_Myths_of_Homeland_and_Return.

Said, E. (1979).Orientalism. New York: Vintage Books.

Shamsie, K. (2000). Salt and Saffron .Oxford University Press.

Sowell, T. (1994). Race and Culture: A World View .New York: Harper \& Brothers. 